\title{
A new species of peacock spider, Maratus proszynskii sp. nov. (Araneae: Salticidae: Euophryini), from Tasmania, with a review of Maratus in Tasmania, Australia
}

\author{
Julianne M. Waldock \\ Department of Terrestrial Zoology, Western Australian Museum, Locked Bag 49, Welshpool DC, \\ Western Australia, 6986 Australia.
}

Email: julianne.waldock@museum.wa.gov.au

\begin{abstract}
A new species of the peacock spider genus Maratus, M. proszynskii, is described from north-eastern Tasmania, Australia. This species appears most similar to M. velutinus Otto and Hill, 2012, and brings to four the number of described species of Maratus known from Tasmania: M. pavonis (Dunn, 1947), M. harrisi Otto and Hill 2011, M. tasmanicus Otto and Hill 2013, and M. proszynskii sp. nov.
\end{abstract}

KEYWORDS: taxonomy, morphology, peacock spiders, Tasmania, Australia

\section{INTRODUCTION}

The genus Maratus was first described by Karsch (1878), and after being subsumed into Saitis by Bonnet (1958) following Simon (1901), was revalidated by Żabka in 1987. The genus was further expanded when Otto and Hill (2012) synonomised Lycidas Karsch, 1878, thus expanding Maratus to cover more than 45 species, with another six recently described species $(M$. madelineae Waldock, 2014, M. hortorum Waldock, 2014, M. jactatus Otto and Hill, 2015a, M. sceletus Otto and Hill, 2015a, M. elephans Otto and Hill, 2015b and M. personatus Otto and Hill, 2015c) bringing the total number to 55 described species at the time of writing (World Spider Catalog, 2015).

Recent work by Maddison (2015) has confirmed the placement of Maratus within the Tribe Euophyrini, a monophyletic group (based on molecular data) which has a cosmopolitan distribution and includes many Australasian taxa.

This study documents the description of Maratus proszynskii sp. nov. from specimens collected in heathlands of northeastern Tasmania for a spider survey supported by the Plomley Foundation. Additionally, a review of the other three named species of Maratus from Tasmania includes M. tasmanicus Otto and Hill, $M$. pavonis (Dunn), and M. harrisi Otto and Hill.

\section{MATERIAL AND METHODS}

Material examined for this study is lodged in the Queen Victoria Museum and Art Gallery, Launceston,
Tasmania, Australia (QVM), Tasmanian Museum, Hobart, Tasmania, Australia (TM) and Australian Museum, Sydney, New South Wales, Australia (AM).

Specimens were preserved and described in 75\% ethanol, illuminated with Halogen lights, and illustrated with the abdomen and cephalothorax in a horizontal position. Female genitalia were examined by dissecting epigynes and clearing them in $10 \%$ lactic acid overnight. Epigynes were mounted in glycerol and illustrated with a camera lucida on a Leica DM 2500 compound microscope. Other drawings and measurements were made using a Leica MS5 or Leica MZ16A stereo microscope and Leica Application Suite V3.8.0 from Leica Microsystems Ltd.

\section{TAXONOMY}

Family Salticidae Blackwall, 1841

Subfamily Salticinae Blackwall, 1841

Tribe Euophryini Simon, 1901

Genus Maratus Karsch, 1878

Maratus Karsch, 1878: 27.

\section{TYPE SPECIES}

Maratus amabilis Karsch, 1878, by subsequent designation of Bonnet (1957: 2713). 


\section{COMPOSITION}

At the time of writing, the World Spider Catalog (2015) listed 55 species under the genus Maratus.

\section{REMARKS}

The specific (and often spectacular) colour patterns on male Maratus species are the result of specialised short squamous setae which cover the dorsal abdominal scute and parts of the dorsal carapace, however in the two species discussed in this paper, M. velutinus Otto and Hill, 2012 and M. proszynskii sp. nov., the squamous abdominal setae are lengthened and noticeably extend beyond the posterior edge of the abdomen (Figures 1-2; see also Otto and Hill, 2012, figure 67(2)).

In other species of Maratus it has been noted that when preserved in alcohol, the vibrancy of the colours of the squamous setae may be reduced, e.g. setae that appear red in life will show as orangey to light brown and with $M$. proszynskii sp. nov. this is compounded by the fading of the specimens over time so that the once black long squamous setae on the abdomen range from dark brown through to orangey brown.

\section{Maratus proszynskii sp. nov.}

Prószyński's peacock spider

http://zoobank.org/urn:Isid:zoobank.org:act:7696C5CC2992-47C3-98AE-56E872DA961E

Figures 1-9

\section{MATERIAL EXAMINED}

\section{Holotype}

Australia: Tasmania: $\hat{\jmath}$, Eddystone Point, Mt William National Park, site 4, 4100'02"S 148 19'15"E, October 1987, T. Churchill (QVM 13:1257).

\section{Paratypes}

Australia: Tasmania: 1 , Eddystone Point, Mt William National Park, site 3, 4059'44'S 148¹9'27'E, October 1986, T. Churchill (QVM 13:186); 10 ふै, 1

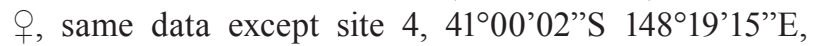
October 1986, T. Churchill (QVM 13:175, 13:178-9, 13:180-4, 13:187); 17 ऽ̃, 3 o, same data except site 4, 4100'02”S 148¹9'15'E, November 1986, T. Churchill (QVM 13:155, 13:158，13:164，13:167-9，13:297，13:716, $13: 160-1,13: 154,13: 163,13: 157) ; 3$ ๙ै, 2 ㅇ, same data

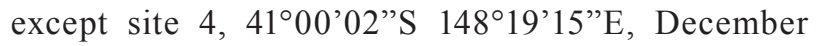
1986, T. Churchill (QVM 13:190, 13:193-4,13:191,

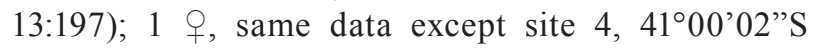
148¹9'15”E, May 1987, T. Churchill (QVM 13:1200); 1 O, same data except site 3, 4059'44'S 148 19'27'E, October 1987, T. Churchill (QVM 13:3470); 12 ô, 1

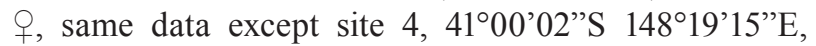
October 1987, T. Churchill (QVM 13:1253-4, 13:1258, 13:1259, 13:1260, 13:1262-4, 13:1267, 13:1273, 13:3313,

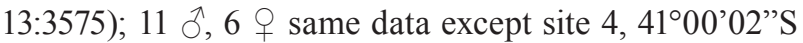
$148^{\circ} 19^{\prime} 15^{\prime \prime} \mathrm{E}$, November 1987, T. Churchill (QVM $13: 1225,13: 1227,13: 1230,13: 1232,13: 1234-5,13: 1236$, $13: 1238,13: 1239,13: 1241,13: 1242,13: 1244,13: 1245$, $13: 1246,13: 1274,13: 3915,13: 19531) ; 7$ กิ, 3 o, same data except site 4, 41 ${ }^{\circ} 00^{\prime} 02^{\prime}$ 'S 148 $19^{\prime} 15^{\prime \prime} \mathrm{E}$, December 1987, T. Churchill (QVM 13:1204, 13:1206, 13:1215, $13: 1217,13: 4231,13: 1210-1,13: 1218) ; 1$ q, same data except site 3, 4059'44'S 148 19'27'E, January 1988, T. Churchill (QVM 13:4594); 1 \%, same data except site

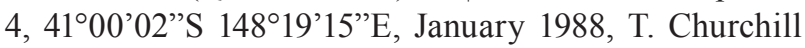
(QVM 13:4595).

\section{Additional material}

Australia: Tasmania: 1 ô, Waterhouse Point [Waterhouse Conservation area], site 1, 4050'51"S 147³8'07'E, October 1986, T. Churchill (QVM 13:84); 1 ơ, same data except site 2, 4050'20”S $147^{\circ} 40^{\prime} 45^{\prime \prime} \mathrm{E}$, October 1986, T. Churchill (QVM 13:188); 2 ふ̄, same data except site $1,40^{\circ} 50$ '51'S $147^{\circ} 38^{\prime} 07^{\prime \prime} \mathrm{E}$, November 1986, T. Churchill (QVM 13:171, 13:174); 1 ふै, same data except site 2, 4050'20'S 14740'45'E, November 1986, T. Churchill (QVM 13:159); 1 \%, same data except site 1, 4050'51'S 147³8'07'E, January 1987, T. Churchill (QVM 13:1193); 1 ふै, 1 †, same data except site 1, 4050'51'S 147³8'07'E, November 1987, T. Churchill (QVM 13:1243); 1 ô, 1 क, same data except site 2, 4050’20”S 14740`45”'E, November 1987, T. Churchill (QVM 13:1240, 13:1237).

\section{DIAGNOSIS}

Males of Maratus proszynskii sp. nov. can be distinguished from all other known species of Maratus, other than M. velutinus, by the presence of elongate rather than truncate squamous setae on the abdominal scute (which extend noticeably beyond the posterior edge of the scute: see Figure 2), and by the lack of abdominal flaps and lack of thick brushes on leg III (Figure 3). Maratus proszynskii sp. nov. differs from $M$. velutinus by the presence of an anterior narrow band of mauve-grey/blue-green squamous setae, by an elongate central stripe anterior to a small mauve-grey/blue-green central spot, and by the presence of short brownish bristles within the ocular quadrangle and white setae around the anterior eyes, and by the absence of a strip of white setae posterior to the fovea (Figure 1). In contrast, $M$. velutinus has reddish bands extending behind the anterior eyes, broad white bands between these eyes, and a broad band of white setae extending from between the AME and beyond the fovea to a point three-quarters down the length of the pars thoracica (see Otto and Hill 2012, figures 68, 69).

\section{DESCRIPTION}

\section{Male (holotype)}

Cephalothorax black to dark brown with white setae bordering lateral edges and clypeus. No squamous setae. Dense patches of fine white setae extend from behind 

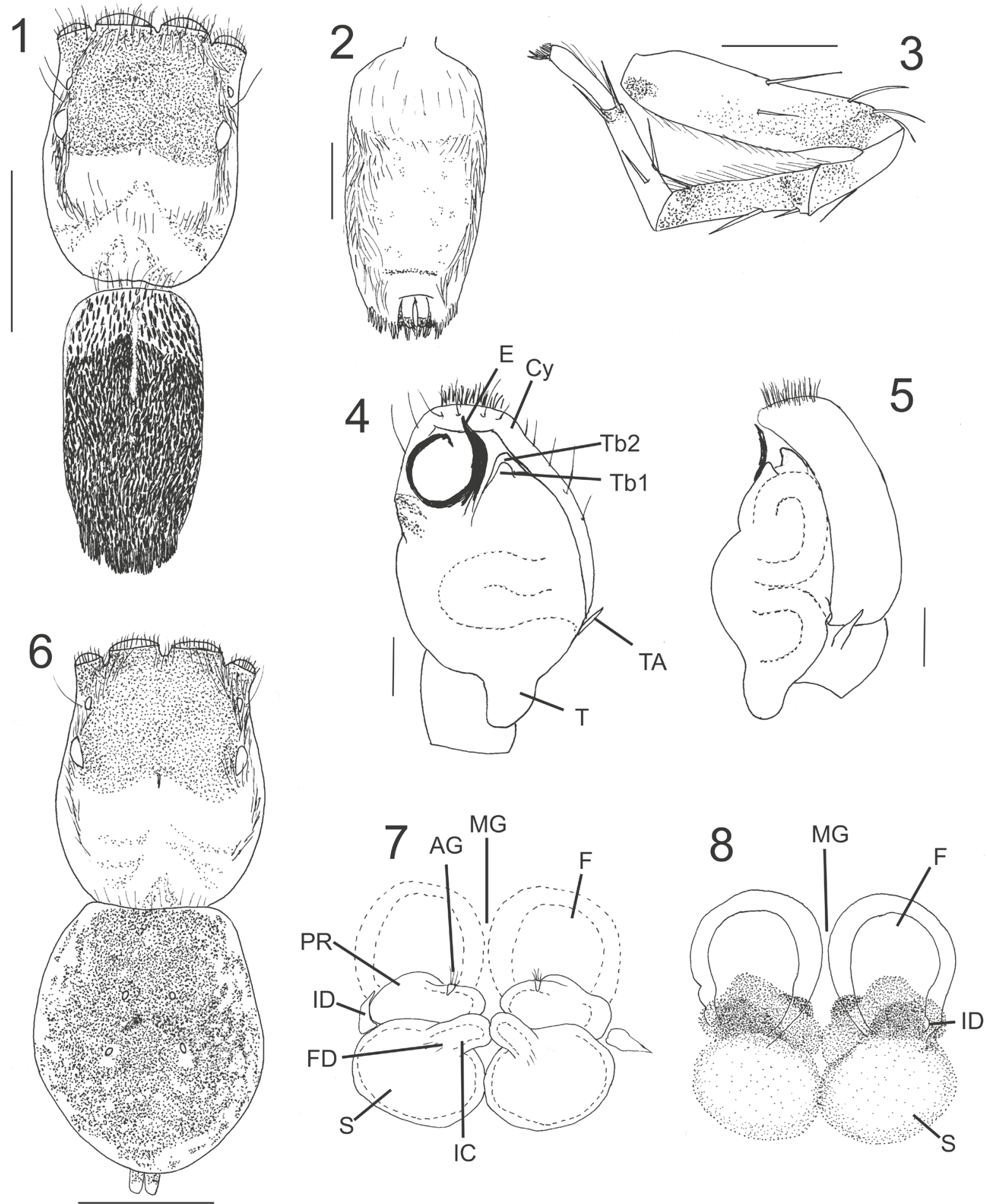

FIGURES 1-8

Maratus proszynskii sp. nov., male holotype (OVM 13:1257): 1, cephalothorax and abdomen, dorsal view; 2, abdomen, ventral view; (OVM 13:1257): 3, left leg III, prolateral view; 4, left pedipalp, ventral view (QVM 13: 1243); 5, left pedipalp, retrolateral view (OVM 13:1243). Female paratype (QVM 13:3470): 6, cephalothorax and abdomen, dorsal view; 7, cleared epigyne, dorsal view; 8, epigyne, ventral view. Scale lines = $1 \mathrm{~mm}$ (Figures 1, 6), $0.5 \mathrm{~mm}$ (Figures 2, 3), $0.1 \mathrm{~mm}$ (Figures 4, 5), $0.2 \mathrm{~mm}$ (Figs 7, 8). Cy = cymbium; $\mathrm{E}=$ embolus; $\mathrm{T}$ = tegulum; $\mathrm{TA}=$ tibial apophysis; $\mathrm{TB} 1-2=$ tegular bulges $1-2 ; \mathrm{AG}=$ accessory gland; $F=$ fossa; $F D=$ fertilisation duct; $I C=$ intermediate canal; $I D=$ insemination duct; $\mathrm{MG}=$ median guide; $\mathrm{PR}=$ proximal receiver $\mathrm{S}=$ spermatheca . 
anterior lateral eyes, below posterior lateral eyes and along sides of cephalothorax, dissipating before steep drop to posterior margin; no white patch of short setae posterior to fovea. Anterior eyes fringed with creamy setae along dorsal margin; rest of cephalothorax lightly covered with scattered short white setae and brown bristles (Figure 1). Clypeus tan, chelicerae tan, cream distally. Maxillae light brown, labium tan with cream edge. Sternum tan.

Venter of abdomen dark yellow with greyish smudges anteriorly, border above spinnerets dark grey; spinnerets grey. Venter posterior to epigastric furrow covered with pelt of long cream setae, densest along border with dorsal scute. Dorsal abdominal scute not developed as lateral flaps (Figure 2). Entire dorsum densely covered in dark brown elongate squamous setae, except for a very small central spot of mauvegrey/blue-green short squamous setae and a narrow central elongate stripe extending from anterior margin of abdomen to just above the central spot (Figure 1). Posterior border of abdominal scute fringed with elongate brown squamous setae which extend over spinnerets (Figures 1, 2). Anterior third of dorsum lighter brown than rest (Figure 1), edged with thin line of mauve-grey/blue-green short squamous setae, no stiff bristles at anterior corners of abdomen. Stiff long brown bristles projecting from anterior border of abdomen (Figure 1). Abdomen swollen anteriorly raising anterior part of scute, exposed sides of abdomen with greyish patterning, no squamous setae. The long venter setae do not extend onto these lateral regions (Figure 2).

Legs I, II, III and IV: proximal femora pale yellow dorso-anteriorly with dark grey patches ventroposteriorly; patellae and tibiae tan; metatarsi and tarsi pale yellow with grey bands at joints; covered with dense short white setae interspersed with black bristles. Leg III: patella, tibia, metatarsus and tarsus with brush of fine white setae dorso-ventrally. No long setae covering claws (Figure 3).

Pedipalpal femur grey, distal segments creamy yellow. Tibial apophysis straight, narrowing distally from a broad base (Figure 5). Cymbium, dorsal tibia and dorsal patella densely covered with long white setae, a single very long black seta on dorsal pedipalpal patella; tibia and cymbium with a few long creamy setae on ventral side just under tegulum. Embolus with broad tip and conductor closely aligned with embolus into tight coil, tucked under tip of cymbium; tegulum with two bulges adjacent to embolus (Figure 4).

\section{Female (paratype, OVM 13:3470)}

Ocular region tan, densely covered with short brown setae; areas around eyes black-brown with white setae in patches around all eyes; rest of cephalothorax yellowish-grey with scattered brown setae. With pale grey bands posterior to ocular area (Figure 6). Clypeus light yellow; chelicerae yellow with light grey patches, maxillae, labium light yellow with white border. Sternum yellow with light grey edging.

Abdomen oval with tan dorsal sigillae and brown bristles scattered amongst brown and creamy setae; most of dorsum covered in diffuse greyish patch on creamy background that narrows to point above spinnerets, three creamy chevrons between posterior sigillae and spinnerets (Figure 6). Venter of abdomen cream, with small grey spots in longitudinal rows. Ventral spinnerets cream, dorsal pair light grey.

Femora and patellae of all legs creamy; dorsal femora of legs III and IV with light grey central stripe, femora I and II with grey stripe only in proximal third; all leg segments except metatarsi I and II and tarsi I to IV with light grey patches at joints; all femora with light grey patches ventro- and posterolaterally.

Proximal receivers of epigyne large, separated from each other at median guide. Intermediate canals abutting each other across median guide, resting on spermathecae, openings directed off-centre of anterior of spermathecae. Insemination duct opening on lower lateral border of fossae (Figures 7-8).

\section{Dimensions (mm)}

Holotype $\delta$ (paratype + , QVM 13:3470): total length (excluding chelicerae) 3.36 (4.03). Carapace length 1.60 (2.08). Abdomen length 1.70 (2.08). Leg I: femur 0.64 (0.84), patella $0.42(0.62)$, tibia $0.46(0.42)$, metatarsus $0.40(0.31)$, tarsus $0.34(0.27)$. Leg II: femur $0.59(0.86)$, patella $0.46(0.60)$, tibia $0.41(0.42)$, metatarsus 0.37 (0.37), tarsus 0.33 (0.37). Leg III: femur 1.14 (1.39), patella $0.50(0.64)$, tibia $0.70(0.73)$, metatarsus 0.54 (0.68), tarsus $0.36(0.33)$. Leg IV: femur 0.84 (1.04), patella $0.36(0.65)$, tibia $0.59(0.68)$, metatarsus 0.48 (0.75), tarsus $0.35(0.43)$. Legs, relative lengths: III: IV: I: II/III: IV: II: I.

\section{DISTRIBUTION}

Maratus proszynskii has been collected from two widely separated locations of heathland (for site descriptions see Churchill, 1996) in northeastern Tasmania, namely Mount William National Park (two sites near Eddystone Point) and Waterhouse Conservation Area (two sites near Waterhouse Point) (see Figure 9). Waterhouse and Eddystone Points are approximately $58 \mathrm{~km}$ apart, with the intervening habitat consisting of areas that have been cleared for farmland and other purposes. Mount William National Park (Eddystone Point) is the larger reserve, now consisting of 18,425 hectares, first established in 1973 (MWNP, 2010). Tracey Churchill's (1996) study sites 3 and 4 were located up to $800 \mathrm{~m}$ inland from the beach zone on the coast south of Eddystone Point. The Waterhouse Point sites, in Waterhouse Conservation Area (WCA), are less than $600 \mathrm{~m}$ from the beaches on the eastern and western sides of the point. The WCA extends in a narrow band 


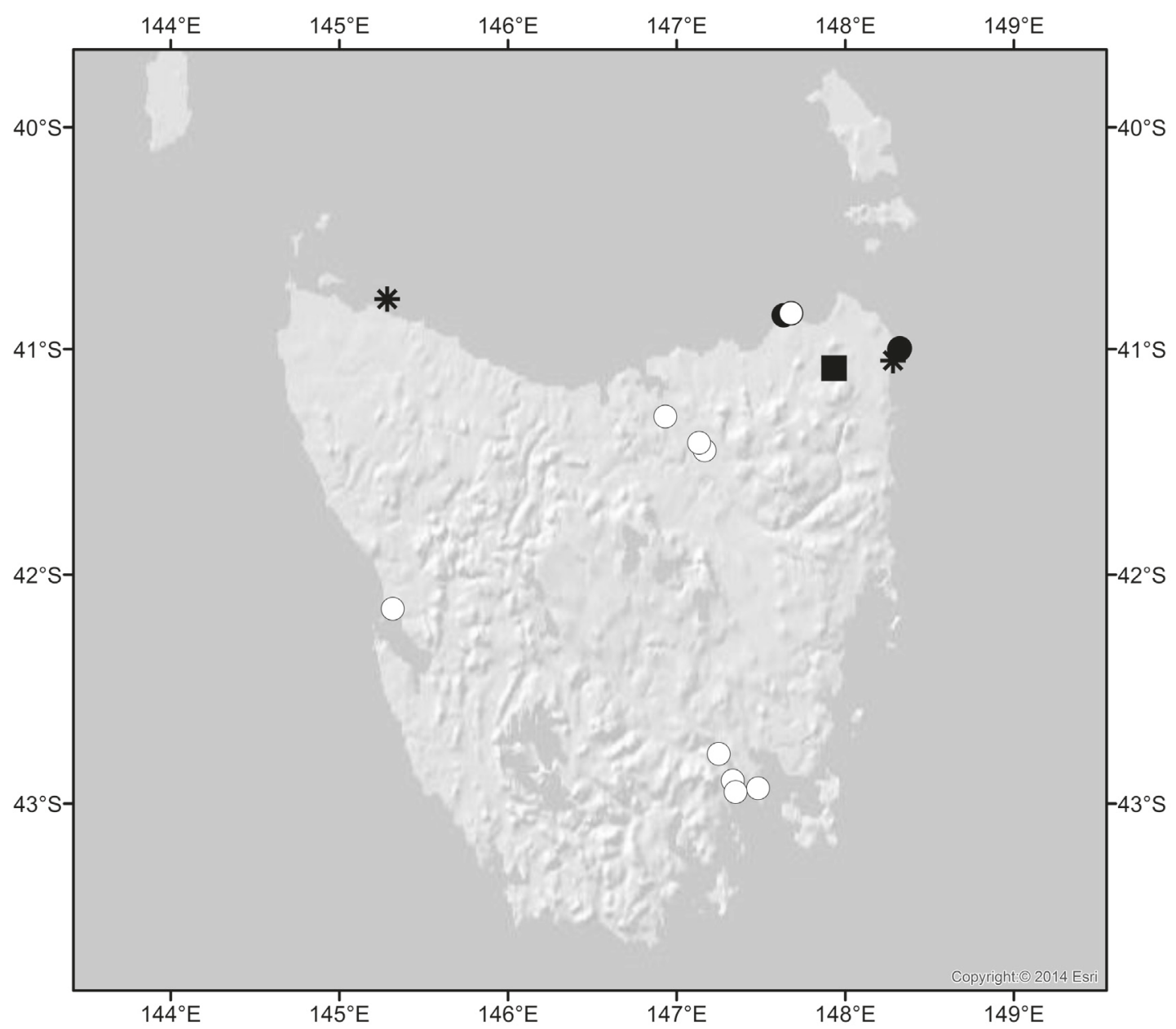

FIGURE $9 \quad$ Map of Tasmania with the collection sites for Maratus proszynskii sp. nov. (closed circles); Maratus pavonis (open circles); Maratus harrisi Otto and Hill, 2011 (closed square); Maratus tasmanicus Otto and Hill, 2013 (asterisks).

from around the point and south-westerly along the coast, encompassing 6, 953 hectares and one of the largest areas of heathland on the Tasmanian northeast coast (WCAMP 2003).

\section{REMARKS}

Maratus proszynskii closely resembles M. velutinus, with the males of both species possessing dark-brown to black elongate squamous setae, and lacking brushes on leg III and lateral abdominal flaps (see Otto and Hill, 2012). In addition to the differences in colour pattern on the carapace and abdomen (see Diagnosis, above), the males of $M$. velutinus are slightly larger than those of $M$. proszynskii, with the total length of $M$. velutinus ranging from 3.25 to $4.20 \mathrm{~mm}$ averaging $3.76 \mathrm{~mm}(\mathrm{n}=$ 7), whilst $M$. proszynskii males range from 2.98 to 3.98 $\mathrm{mm}$ averaging $3.43 \mathrm{~mm}(\mathrm{n}=10)$.

Otto and Hill (2012) describe the embolic tip of $M$. velutinus as consisting of the apices of the inner and outer rings of the embolus which present a prominent distal apex (see Otto and Hill 2012, figures 67-5, -6, $-7)$; this statement is interpreted here as referring to the conductor being shorter than the embolus resulting in the embolus tip extending above the tip of the conductor. This arrangement of the embolus and conductor has been noted by Żabka (1987: page 472), "[e]mbolus narrow, forming a single coil, accompanied by a shorter strongly sclerotized conductor". Upon comparison the embolic tip of $M$. velutinus is broader than that of $M$. proszynskii but the overall arrangement of the embolus and conductor does not differ significantly (see Figures $4,5)$.

The female of $M$. velutinus is unknown so it is not possible to compare them with $M$. proszynskii.

Both $M$. velutinus and $M$. proszynskii share characters that separate them from the more spectacular species of 
Maratus. The lack of brightly coloured squamous setae on the abdomen, lack of squamous setae in the optical quadrangle and most significantly, the lack of brushes on leg III suggest that these two species may be closely related.

\section{ETYMOLOGY}

The specific epithet is a patronym in honor of Polish Professor Dr Jerzy Prószyński, who, since 1969, has dedicated a lifetime to salticid systematics.

\section{Maratus tasmanicus Otto and Hill, 2013}

Maratus tasmanicus Otto and Hill, 2013: 14, figs $15-25$.

\section{MATERIAL (NOT EXAMINED)}

Australia: Tasmania: Stanley, 4046’30.71"S

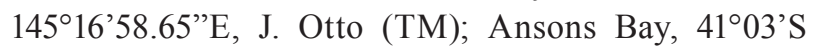
148¹7’E, 1 January 1929, V. V. Hickman (AM KS30911) as listed in Otto and Hill, 2013.

\section{Maratus pavonis (Dunn, 1947)}

Saitis pavonis Dunn, 1947: 83.

Maratus pavonis (Dunn): Żabka, 1991: 39; Otto and Hill, 2014: 46, figs 52-55.

\section{MATERIAL EXAMINED}

Australia: Tasmania: $1 \sigma^{\lambda}$, no data, (QVM 13:42186);

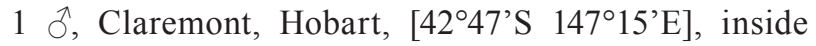
house, 5 December 1982, B. Watson, (TM J2721); 2 ㅇ, Exeter [4118'S 14656'E], 21 November 1970, R. T. G.

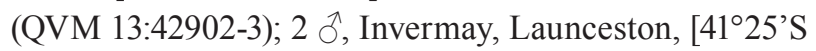
$\left.147^{\circ} 08^{\prime} \mathrm{E}\right], 19$ March 1996, V. Case (QVM “1796”);

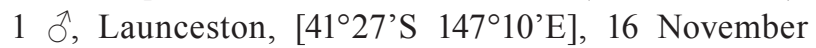
1970, R. Upsom (QVM 13:42904); 1 ô, Launceston,

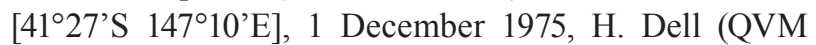
13:42905); 1 त [abdomen missing], Lower Sandy Bay, Hobart, [42 $54^{\prime}$ 'S 147²0’E], 2 November 1975, E. L. Martin, (TM J1079); 1 $\hat{\jmath}$, same locality, E. L. Martin, (TM J1161); 1 ô, same locality, 13 December 1983,

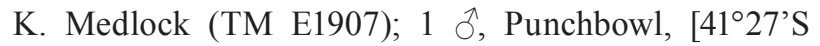
$147^{\circ} 10^{\prime} \mathrm{E}$ ], 26 November 1994, G. Finnigan (QVM

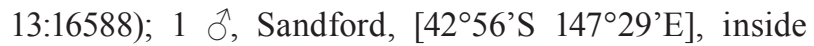
of window in house, 30 October 1984, M. Gaffney, (TM J1936); 1 ○, Strahan, Melaleuca swamp, [4209’S $\left.145^{\circ} 19^{\prime} \mathrm{E}\right]$ on ground cover, 15 November 1973, K. C. Collins (AM KS17120); 1 ふૈ, Taroona, [4257’S 147²1'E], 5 January 1977, R. J. Burns, (TM J1171); 1 đ, 1 q [very faded], Waterhouse Point, site 2, 4050’20”S 14740`45”'E, Dec. 1987, T. Churchill (QVM 13:1203).

\section{Other Tasmanian Maratus Species}

Maratus harrisi Otto and Hill, 2011

Maratus harrisi Otto and Hill, 2011: 4, figs 4-10.

\section{MATERIAL EXAMINED}

Australia: Tasmania: 1 $\hat{\partial}$, Friend Creek, E of Pioneer, in pitfall trap in open bracken, $\left[41^{\circ} 05^{\prime} \mathrm{S}\right.$ 14756’E], 27 March 1990, R.Taylor (TM J3113).

\section{ACKNOWLEDGEMENTS}

I am grateful to the Queen Victoria Museum and Art Gallery, Launceston, Tasmania, Tasmanian Museum, Hobart, Tasmania and Mr Graham Milledge of the Australian Museum, Sydney for the loan of the material used in this study. I am also most grateful for additional assistance from the anonymous referees.

\section{REFERENCES}

Blackwall, J. (1841). The difference in the number of eyes with which spiders are provided proposed as the basis of their distribution into tribes; with descriptions of newly discovered species and the characters of a new family and three new genera of spiders. Transactions of the Linnean Society of London 18: 601-670.

Bonnet, P. (1957). Bibliographia Araneorum, 2(3). Douladoure: Toulouse.

Bonnet, P. (1958). Bibliographia Araneorum, 2(4). Douladoure: Toulouse.

Churchill, T. B. (1996). Coastal heathland spiders: spatial distribution and biogeographic significance. Records of the Queen Victoria Museum Launceston 103: 151-158.

Dunn, R. A. (1947). A new salticid spider from Victoria. Memoirs of the National Museum of Victoria 15: 82-85.

Karsch, F. (1878). Diagnoses Attoidarum aliquot novarum Novae Hollandiae collectionis Musei zoologici Berolinensis. Mitteilungen des Münchener Entomologischen Verein, München 2: 22-32.

Maddison, W. P. (2015). A phylogenetic classification of jumping spiders (Araneae: Salticidae). Journal of Arachnology 43: 231-292.

MWNP. 2010. Mt William National Park Reservation History (http://dpipwe.tas.gov.au/Documents/Reservation-HistoryMount-William-National-Park.pdf accessed 23 January 2015).

Otto, J. and Hill, D. (2011). An illustrated review of the known peacock spiders of the genus Maratus from Australia, with description of a new species (Araneae: Salticidae: Euphyrinae). Peckhamia 96 (1): 1-27.

Otto, J. and Hill, D. (2012). Notes on Maratus Karsch 1878 and related jumping spiders from Australia, with five new species (Araneae: Salticidae: Euophryinae). Peckhamia 103 (1): $1-81$.

Otto, J. and Hill, D. (2013). Three new Australian peacock spiders (Araneae: Salticidae: Maratus). Peckhamia 108 (1): $1-39$. 
Otto, J. and Hill, D. (2015a). Two new peacock spiders of the calcitrans group from southern Queensland (Araneae: Salticidae: Euophryinae: Maratus). Peckhamia 121 (1): $1-34$.

Otto, J. C. and Hill, D. E. (2015b). Maratus elephans, a new member of the volans group from New South Wales (Araneae: Salticidae: Euophryinae). Peckhamia 123 (1): $1-19$.

Otto, J. C. and Hill, D. E. (2015c). Maratus personatus, a masked peacock spider from Cape Riche, Western Australia (Araneae: Salticidae: Euophryinae). Peckhamia 127 (1): $1-30$.

Simon, E. (1901). Histoire Naturelle des Araignées, vol. 2, 381668. Encyclopédie Roret: Paris.

Waldock, J. M. (1995). A new species of Maratus from southwestern Australia (Araneae: Salticidae). Records of the Western Australian Museum, Supplement No. 52: 165-169.

Waldock, J. M. (2008). A new species of Maratus from southwestern Australia (Araneae: Salticidae). Records of the Western Australian Museum 24: 369-373.

Waldock, J. M. (2013). A review of the peacock spiders of the Maratus mungaich species-group (Araneae: Salticidae), with descriptions of four new species. Records of the Western Australian Museum 28: 66 - 81.

Waldock, J. M. (2014). Two new species of peacock spider of the Maratus mungaich species-group (Araneae: Salticidae) from south-western Australia. Records of the Western Australian Museum 29: 149-158.

WCAMP. 2003. Waterhouse Conservation Area Management Plan (http://www.parks.tas.gov.au/file.aspx?id=7076, accessed 23 January 2015)

World Spider Catalog. (2015). World Spider Catalog. Natural History Museum Bern, online at http://wsc.nmbe.ch, version 16.5, accessed on 21 August 2015.

Żabka, M. (1987). Salticidae (Araneae) of Oriental, Australian and Pacific Regions, II. Genera Lycidas and Maratus. Annales zoologici 40: 451-482.

Żabka, M. (1991). Studium taksonomiczno-zoogeograficzne nad Salticidae (Arachnida: Araneae) Australii. Wyższa Szkola Rolniczo-Pedagogiczna $W$ Siedlcach Rozprawa Naukowa 32: $1-110$.

MANUSCRIPT RECEIVED 21 AUGUST 2015; ACCEPTED 2 DECEMBER 2015. 